\title{
THE EFFECT OF USING FULL-ENGLISH AS LANGUAGE OF INSTRUCTION IN IMPROVING CHILDREN'S SPEAKING SKILL
}

\author{
Nita Kaniadewi. Universitas Muhammadiyah Prof. Dr. Hamka \\ nitakaniadewi@uhamka.ac.id \\ Widi Sriyanto. Universitas Muhammadiyah Prof. Dr. Hamka \\ widi.sriyanto@uhamka.ac.id.
}

\begin{abstract}
Abstrak
Penelitian ini merupakan upaya untuk membuktikan keefektifan menggunakan Bahasa Inggris sebagai bahasa pengantar dalam meningkatkan keterampilan berbahasa Inggris anakanak. Pembelaajaran diberikan dalam 6 pertemuan untuk masing-masing kelas kontrol dan kelas eksperimen. Dua jenis rencana pelajaran disusun, satu menggunakan Bahasa Inggris penuh sebagai bahasa pengantar untuk kelas eksperimen dan yang lainnya menggunakan bahasa campuran (kombinasi Bahasa Inggris dan Bahasa Ibu) untuk kelas kontrol. Percobaan dengan desain kuasi-eksperimental dan tes lisan digunakan sebagai metode dan instrumen. Berdasarkan perhitungan uji Chi-square dan Fisher. Hasil dari penelitian ditemukan bahwa data kedua kelas berupa data homogen dan berdistribusi normal. Setelah memenuhi persyaratan, hipotesis diuji dengan menggunakan uji-T pada tingkat signifikansi 0,05 . Temuan menemukan bahwa perhitungan $t$ lebih tinggi dari t-tabel $(+3,25>+1,67)$. Ini menunjukkan bahwa rata-rata kelas eksperimen secara signifikan lebih tinggi dari pada kelas kontrol. Temuan di atas mengarah pada kesimpulan bahwa penggunaan Bahasa Inggris penuh sebagai bahasa pengantar efektif dalam meningkatkan keterampilan berbahasa Inggris anakanak. Namun, karena anak-anak masih pemula dalam Bahasa Inggris, maka disarankan untuk memastikan bahwa Bahasa Inggris yang digunakan oleh guru berada di dalam zona perkembangan proksimal anak-anak. Juga disarankan bagi para guru untuk menggunakan patah alih-alih Bahasa Inggris standar dan untuk menemani input bahasa mereka dengan gerakan agar memberikan makna lebih mudah.
\end{abstract}

Kata Kunci: Bahasa Pengantar, Penguasaan Bahasa Pemula, Bahasa Inggris untuk pemula

\section{INTRODUCTION}

Acquisition is still believed to be one of the best ways to achieve language proficiency. This applies not only to the first language (L1), but also to foreign languages. If L1 acquisition tends to happen quite easily, then things can be a little complicated with foreign language acquisition since it requires learning situations that resemble L1 acquisition. Foreign language classes must be able to create learning conditions that resemble the L1 acquisition. One way is to do this is by providing as many language exposures as possible to students. Students should be bombarded with the target language intensively, similar to the condition experienced by children when acquiring their L1. If it is associated with language learning in schools, then teachers must be able to create learning situation that allows students to be exposed to the target language, in this case English, as frequent as possible. A way to do this is by using English as the language of instruction during the whole lessons. Teachers should speak in full-English not only at certain moments, such as when opening and closing classes, but also when presenting new material, giving reinforcement, responding to students' 
questions, etc. Teachers must use English from the beginning to the end of the lesson, consistently at each meeting, without being interrupted by L1. This intensive use of English is believed will facilitate the process of target language acquisition which in turn will increase the students' speaking skill. This believe is supported by previous study that discovered the subject of the lesson influences the intensity of the target language used in the classroom. Speaking classes will mostly merit from high amount of TL. While on the other hand, grammar classes will not (Brands, 2011). However, another study revealed that students actually benefit from the use of the L1 in the classroom, especially in transferring concepts from their mother tongue to the new language (Salmona, 2014). Considering these facts, this study aims at finding empirical evidence of the effectiveness of using the target language, in this case English, intensively/fully in the classroom in increasing students' speaking skill.

Humans speak in different languages, yet every human goes through the same process in acquiring language. Dardjowidjojo (2005) defines language acquisition as the process performed by children naturally in order to master their mother tongue. When a mother communicates with her child, the child captures all the information given by his mother which is then subconsciously stored in his brain. The part of the human brain that is related to the development of language is known as the faculty of language as explained by Chomsky (2009). He claims that children can acquire and develop language skills because they have what is called innate language faculty or known as the Language Acquisition Device (LAD). The LAD ensures all children undergo the same process of acquiring language, though the duration of the acquisition may differ. In line with the explanation above, Chaer (2009) also states that language acquisition is a process that takes place in a child's brain when he acquires his native language. The experts imply that it is not difficult for a child to acquire his native language since he is equipped with $\mathrm{LAD}$, as long as sufficient language input is given to him.

It should be noted that language acquisition is different from language learning. Learning is the occurrence of new behaviors or reinforcement of old behaviors as a result of experiences both happening explicitly or implicitly (Reynolds, 2005). Jarvis (2006) adds that learning is a change in performance caused by the process of training. The same thing is also conveyed by Witting (1981) that learning is a relatively settled-change that occurs in all human behavior as a result of experience. Learning is the emergence of relatively settled changes that result from exercises, trainings, experiences, or interactions with the environment that are usually systematically planned through formal teaching. Thus, it is clear, language learning, just like any other learning, is a conscious process that requires awareness. On the contrary, language acquisition is an unconscious mental process that leads to language competence. It involves spoken more than written language, happens through direct experience by using lots of natural language as if the interaction between a child and his mother, and therefore is anxiety-free. (Richard and Schmidt, 2002).

The first language (L1) is the language a child knows for the first time in their life. The first language is also known as mother tongue because the language is used by a mother to communicate with her child since the child is born in the world. Crain and Lilo-Martin (1999) 
ensure that the acquisition of the first language in children is always successful even without formal learning unless the child experiences problems related to the development of speech tools or biological problems such as speech impairment. It can be said that a child's physical development and also the stimulus given by his parents and surrounding help the acquisition of the child's L1. According to Krashen (2006), first language acquisition is done unconsciously or without conscious learning as if someone learns language in classrooms. Moreover, Skinner (1957) and Chomsky (2009), have different argument in the discussion of L1 acquisition in children. Skinner believes the success of L1 acquisition in children depends on how often the child is exposed to the language in communication. While Chomsky holds that a child can certainly speak their L1 because since he is born into the world God has provided his brain with the ability to speak. Therefore, the writers believe that $\mathrm{L} 1$ acquisition in children is definitely influenced by all aspects that have been conveyed by Skinner and Chomsky or in other words the opinion is both true that if the child wants to acquire a language he must be given stimulus by people around him especially parents in order to activate the language skills that God has given in the human brain.

Foreign language acquisition is closely related to L1 acquisition, yet there are significant differences between them. One of the differences between foreign and L1 acquisition is that the latter is a definite stage of human's biological and social development, while the former is not. FLA might or might not occur in one's language development, depending on many factors, such the person's personal need, the social and cultural demand, etc. Furthermore, F1 acquisition happens first in which the process starts right after a baby is born. Meanwhile, FLA comes later, usually after the F1 rules are established. Next, L1 acquisition takes place through a child's direct interaction with his closest surroundings, while FLA usually happens through formal teaching at schools. In relation to language mastery, the acquisition of L1 pronunciation is nearly without significant difficulties and error. This is because during the process of L1 acquisition, a child usually does not have another language yet. While in FLA, this condition rarely happens because the child already has his L1 which sometimes interfere the process of FLA.

Brown (2007) says that second/foreign language acquisition is a part of general human learning involving cognitive variations. These variations are related to one's personality and cultural learning which involve the scientific side and communicative functions of a language. This is indicated by the learning stage and the development processes that come in the form of trial and error. Krashen (2006) states that the theory of second language acquisition is a part of theoretical linguistics because of its abstract nature. According to him, in teaching a second language, the practical thing is a sound theory of language acquisition.

The target language is a foreign language or the second language that the learner wants to master. Mastery of the target language is usually based on certain motivations. In this study, the target language learned by students is English which is a foreign language in Indonesia. The success of English teaching for elementary school students is still not satisfactory due to many factors.

Among the factors is the lack of teacher's support to let students experience and be exposed 
with English. Along with this, Nunan (1991) said that success was measured in terms of the ability to carry out conversations in the target language. It can be interpreted that if students do not learn to speak or do not get the opportunity to speak, they will lose interest in learning the language. Conversely, if the speaking lesson is given appropriately, students will get motivation to learn and the classroom atmosphere will be alive and dynamic. Therefore, the use of full-English as the language of instruction can boost students' learning.

Who are young language learners? Learners can be divided into three age groups, namely children, adolescents, and adults. Children are a group of students aged 2 to 12 years, adolescents are a group of students aged between 12 and 17 years, and adults are generally those aged above 17 years (Harmer, 2007). It is clear here that elementary school students belong to the group of children/young learners. Then what are their characteristics? Scott and Ytreberg (2000) explain the general characteristics of children aged 8 to 10 years: (1) their basic concepts are formed; they have a clear view of the world, (2) they can distinguish between facts and fiction, (3) they always ask questions, (4) they believe in verbal words and the physical world to convey and understand meaning, (5) they can make decisions about what they want to learn, (6) they have a clear view of what they like and dislike, (7) they understand the sense of justice that occurs in the classroom, and (8) they can work with and learn from other people. Based on the description above, it can be said that elementary school students belong to the group of children who have their own characteristics that are different from adolescents and adults. Thus, the learning approach must also be distinguished from adolescents and adults.

Below is the description of the theoretical framework of this study. Children, as young language learners, are excellent imitator. Children can easily imitate the pronunciation and accent of a language, including foreign languages. But this did not happen instantly. Children need to be bombarded with the language. They need to interact with and experience the language intensively. A child's experience in acquiring his mother tongue needs to be repeated when he interacts with a foreign language. In other words, foreign language classes must be able to create learning conditions that resemble the first language acquisition. One way to do this is by providing as many language exposures as possible in the class. This means that children are bombarded with the target language, in this case English, on every occasion. This condition is similar to the condition experienced by children when they acquire their mother tongue. If it is associated with learning English in schools, the teacher must be able to create a learning atmosphere that allows students to be exposed to English as often as possible. One way is to make English as a language of instruction in the classroom. As a language of instruction, English is used not only at certain moments, such as when opening and closing the lesson. English must also be used from the beginning to the end of the lesson consistently without interruption by the students' mother tongue and this must be done consistently at each meeting. Teachers should not be tempted to use the mother tongue in the classroom at all. Communication difficulties that possibly occur must be overcome in such a way by using language input that is understood by the students $(i+1)$ and with the help of gestures. The 
high intensity of using English as a language of instruction in the classroom is believed to be able to improve children's English speaking skill.

\section{METHOD}

This research was conducted at an elementary school in East Jakarta in the first semester of 2018-2019 academic years. The method used in this study was the experimental method using a quasi-experimental design (posttest only). Two types of lesson plan were prepared; one used full-English as the language of instruction for the experiment class and the other used mixed English and mother tongue for the control class. To obtain the data that will support this study, a speaking test was used as the instrument. The test was measured using speaking skill rubric which involved five aspects: pronunciation, vocabulary, fluency, grammar, and comprehension. Each aspect was scored from 1 to 5. After the speaking score was obtained, Chisquare and Fisher tests were conducted to test the normality and homogeneity of the scores. Finally, the hypothesis was tested using t-test with the formula below:

$$
t=\frac{\overline{X_{1}}-\overline{X_{2}}}{S_{g a b} \sqrt{\frac{1}{n_{1}}+\frac{1}{n_{2}}}}
$$

The research hypotheses are as follow:

1. $\mathrm{H}_{\mathrm{o}}$ : There is no significant difference between the use of full-English and the use of mixed language (a combination of English and mother tongue) as the language of instruction in improving the students' speaking skill.

2. $\mathrm{H}_{\mathrm{i}}$ : There is significant difference between the use of full-English and the use of mixed language (a combination of English and mother tongue) as the language of instruction in improving the students' speaking skill.

\section{DISCUSSION}

The tables below summarize the data obtained in this study.

Table 1. The Speaking Scores of Both Classes

\begin{tabular}{ccc}
\hline Data & Control Class & Experiment Class \\
\hline Total Score & 2057 & 2106 \\
Average Score & 70.93 & 72.62 \\
\hline
\end{tabular}

Table 2. Interval Class of the Speaking Score from the Control Class

\begin{tabular}{cccccc}
\hline Score & $\mathbf{f}_{\mathbf{i}}$ & $\mathbf{x}_{\mathbf{i}}$ & $\mathbf{f}_{\mathbf{i}} \mathbf{x}_{\mathbf{i}}$ & $\left(\mathbf{x}_{\mathbf{i}}-\overline{\mathbf{x}}\right)^{\mathbf{2}}$ & $\mathbf{f}_{\mathbf{i}}\left(\mathbf{x}_{\mathbf{i}}-\overline{\mathbf{x}}\right)^{\mathbf{2}}$ \\
\hline $50-56$ & 5 & 49.5 & 247.5 & 2450.25 & 12251.25 \\
$57-63$ & 7 & 56.5 & 395.5 & 3192.25 & 22345.75 \\
$64-70$ & 6 & 63.5 & 381 & 4032.25 & 24193.5 \\
$71-77$ & 5 & 70.5 & 352.5 & 4970.25 & 24851.25 \\
$78-84$ & 3 & 77.5 & 232.5 & 6006.25 & 18018.75 \\
$85-91$ & 3 & 84.5 & 253.5 & 7140.25 & 21420.75 \\
$\Sigma$ & 29 & & 1862.5 & & 123081.25 \\
\hline
\end{tabular}

From the data above, it was found that the standard deviation ( $\mathrm{s}$ )for the control class was $\mathrm{s}=$ 11.122

Table 3. Interval Class of the Speaking Score from the Experiment Class

\begin{tabular}{ccccccc}
\hline Score & $\mathbf{f}_{\mathbf{i}}$ & $\mathbf{x}_{\mathbf{i}}$ & $\mathbf{f i x}_{\mathbf{i}}$ & $\mathbf{x}_{\mathbf{i}}-\overline{\mathbf{X}}$ & $\left(\mathbf{x}_{\mathbf{i}}-\overline{\mathbf{X}}\right)^{\mathbf{2}}$ & $\mathbf{f}_{\mathbf{i}}\left(\mathbf{x}_{\mathbf{i}}-\overline{\mathbf{X}}\right)^{\mathbf{2}}$ \\
\hline $50-57$ & 5 & 49.5 & 247.5 & 2450.25 & 12251.25 & $50-57$ \\
$58-65$ & 5 & 57.5 & 287.5 & 3306.25 & 16531.25 & $58-65$ \\
$66-73$ & 4 & 65.5 & 262 & 4290.25 & 17161 & $66-73$ \\
$74-81$ & 6 & 73.5 & 441 & 5402.25 & 32413.5 & $74-81$ \\
$82-89$ & 5 & 81.5 & 407.5 & 6642.25 & 33211.25 & $82-89$ \\
$90-97$ & 4 & 89.5 & 358 & 8010.25 & 32041 & $90-97$ \\
$\Sigma$ & 29 & & 2003.5 & & 143609.25 & 29 \\
\hline
\end{tabular}

From the data above, it was found that the standard deviation (s)for the experiment class was $\mathrm{s}=13.621$.

Before the data were calculated by using ttest, Chi-square and Fishers tests were undertaken in order to find out the normality and homogeneity of the data. The results showed that the data were normal and homogeneous. The analysis was then continued with the hypothesis testing by using t-test. Below is the calculation.

$$
\overline{X_{1}}=69.10 \quad \overline{X_{2}}=64.22
$$




$$
\begin{array}{ll}
\mathrm{N}_{1}=29 & \mathrm{~N}_{2}=29
\end{array}
$$$$
S_{\text {gab }}=\frac{\left(n_{1}-1\right) S_{1}^{2}-\left(n_{2}-1\right) S_{2}^{2}}{n_{1}+n_{2}-2}
$$

$S_{\text {tot }}=5.65$

$$
\begin{aligned}
& t=\frac{\overline{X_{1}}-\overline{X_{2}}}{S_{\text {tot } \sqrt{\frac{1}{n_{1}}+\frac{1}{n_{2}}}}} \\
& =\frac{69.10-64.22}{5.65 \sqrt{\frac{1}{29}+\frac{1}{29}}} \\
& =\frac{4.88}{1.5}=3.25 \\
& \text { Formula for df } \quad=\left(\mathrm{N}_{1}+\mathrm{N}_{2}-2\right) \\
& =(29+29-2) \\
& =56
\end{aligned}
$$

The hypothesis testing used one-tail testing at significance level $\alpha=0.05$ and degree of freedom $(\mathrm{df})=56$; the t-table was 1.67. As is known, $\mathrm{H}_{\mathrm{o}}$ is rejected if $\mathrm{t}$-computation is higher than t-table. From the results of the independent $\mathrm{t}$ test, the average score of the speaking test of the experiment class was significantly higher than the control class and t-computation > t-table, (3.25> 1.67).

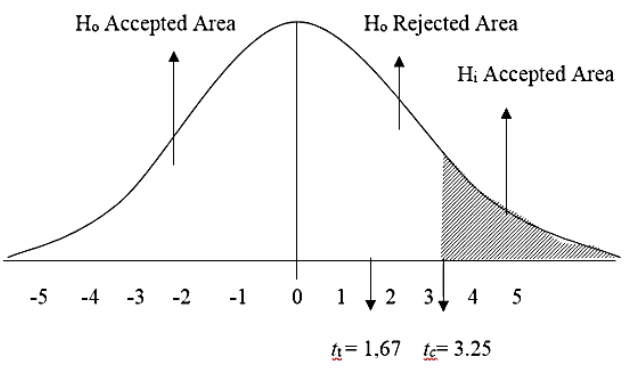

Picture 1.Hypothesis Testing Curve

The above curve shows that $\mathrm{H}_{\mathrm{o}}$ is rejected and $\mathrm{H}_{\mathrm{i}}$ is accepted. This reveals that the use of full-English as the language of instruction is more effective and has more positive impact in improving children's English speaking skill than the use of mixed language (a combination of English and the students' mother tongue).

As explained earlier, children, as young language learners, are great imitators. Children can easily mimic the pronunciation and accent of a language, including foreign languages. Yet, this does not happen immediately. Children need to interact directly, experience directly, or be bombarded with the languages intensively. Children's experiences in acquiring their mother tongue need to be repeated when they interact with a foreign language. In other words, foreign language classes must be able to create learning conditions that resemble first language acquisition. One way is to provide as many language exposures as possible. This means that children are bombarded with these foreign languages, in this case English, on every occasion. If it is associated with learning English in schools, teachers must be able to create a learning atmosphere that allows students to be exposed to English as often as possible. One way to do this is to make English as the language of instruction in the classroom. As a language of instruction, English is used not only at certain moments. Yet, English must be used from the beginning to the end of the lesson consistently without interruption by the students' mother tongue. Teachers should not be tempted to use the mother tongue in the classroom at all. Communication difficulties must be overcome in such a way by using language input that is understandable by the students and with the help of gestures. The high intensity of English as the language of instruction ultimately enables to significantly improve the students' English speaking skills.

At first, the writer had difficulty in using English as the only language of instruction 
intensively in the classroom (in the experimental class). The number of students was quite large for a language class, 30 students in one class. The schedule of the lesson was also close to lunch hour (11.00-12.00 p.m.), making the classroom atmosphere less conducive. In addition, these students were previously not used to full-Englishspeaking teachers. These realities made the students often not understand what the writer was saying and thus took the writer more time to convey meaning and messages properly. Moreover, though the order of language acquisition should be listening, speaking, reading, and writing, some students (around 50\%) immediately opened their textbooks and read the material in the textbooks when the writer was presenting the new material orally for the first time. This indicated that they were not used to hearing the language; they were more used to reading the language, even for the very first time, and this did not resemble the correct order of language acquisition. This condition happened because the school English teacher used more mother tongue than English as the language of instruction during the lessons. Furthermore, the students were more used to written exercises than oral practices. Therefore, once the students were taught by a full-English-speaking teacher, they looked very unfamiliar, lack of focus, lack of listening, and preferred to flick through their textbooks. As a result, in the first and second treatment, what happened in the classroom was the adjustment of new habits. The writer adjusted to the conditions of students and students adjusted to be taught by a full-English-speaking teacher.

It was in the third and fourth treatment, did the students begin to adapt to the use of fullEnglish in the classroom. They understood faster and easier what the writer was saying. And at the fifth and sixth treatment, both the writer and the students finally were more accustomed to and enjoyed full-English usage in the classroom. Communication patterns and exposure models had shifted. Classroom communication, which initially tended to use mother tongue, had changed to the use of full-English. The exposure model that had previously rely more on reading textbooks began to prioritize oral presentation. Another important thing was the English used by teachers. It must be inside the students' zone of proximal development. In other words, in order to determine the level of language input used in the classroom, teachers must be aware of the students' English level of proficiency. Forcing to use standardized English will make the students confused and frustrated. It is advisable to use $\mathrm{i}+$ 1 language input, English which is only one level above the students' level of proficiency. In addition, it was also discovered that the use of non-verbal language, such as gestures, facial expressions, and voice intonation, did facilitate the delivery of meaning and messages.

\section{CONCLUSION}

Based on the findings, it was known that at the significance level $\alpha=0.05$ and degrees of freedom $(\mathrm{df})=56, \mathrm{t}$-computation $>\mathrm{t}$-table, $(3.25$ $>$ 1.67). Therefore, $H_{0}$ was rejected and $H_{i}$ was accepted. Thus, it can be concluded that the use of the full-English as the language of instruction was more effective and had a positive impact than the use of mixed language (a combination between English and the students' mother tongue) in improving students' English speaking skills.

Moreover, some suggestions can be given regarding experimental research using fullEnglish as the language of instruction as follow. Teachers are strongly advised to use English as 
the language of instruction during the lesson in order to improve the students' speaking skill. However, it is very crucial to consider beforehand the kind of English suitable for classroom use. The language input used as the language of instruction have to be inside the students' Zone of Proximal Development. The English used by the teacher should not be too far from the student's English proficiency level. The teacher must pay attention to the level of the student's English proficiency level and adjust it to the level of the English he uses in the classroom. It should not be any higher than $i+1$. Moreover, teachers should use broken English accompanied by gestures to facilitate the delivery of meaning. These things really help smoothen teacher-student communication and avoid communication breakdown. The writer hopes that the results of this study can be a reference and supporting literacy for similar research in the future.

\section{REFERENCES}

Brown, H.D. (2007). Principles of Language Learning and Teaching. London: Longman.

Chaer, A. (2009). Psikolinguistik Kajian Teoretik. Jakarta: RinekaCipta.

Chomsky, N. (2009). Cartesian Linguistics A Chapter in The History of Rationalist Thought (James McGilvrayed.). New York: Cambridge University Press.

Crain, S \&Lilo-Martin, D. (1999). An Introduction to Linguistic Theory and Language Acquisition. Malden: Blackwell Publishing.

Dardjowidjojo, S. (2005). Psikolinguistik Pengantar Pemahaman Bahasa Manusia. Jakarta: Yayasan Obor Indonesia.

Harmer, J. (2007). How to Teach English. Essex: Pearson Education Limited.
Jarvis, P. (2006). Towrads a Compreensive Theory of Human Learning. New York: Routledge Publishers Inc.

Krashen, S.D. 2006. Principles and Practice in Second Language Acquisition. California: University of Southern California.

Nunan, D. (1991). Language Teaching Methodology: A Text Book for Teacher. Cambridge: Combridge University Press.

Reynolds, S. (2005). Learning is a Verb - The Psychology of Teaching and Learning ( $2^{\text {nd }}$ ed.). New York: Routledge Publishers Inc.

Richard, J.C. \& Schmidt, R. (2002). Longman Dictionary of Language Teaching and Applied Linguistics. London: Pearson Education Ltd.

Scott, W.A. \& Ytreberg, L.H. (2000).Teaching English to Children. New York: Longman Group UK Ltd.

Salmona, M. (2014), The Use of First Language in the Second-Language Classroom: A Support for Second Language Acquisition. Gist Education and Learning Research Journal, No. 9 (July-December), pp. 5066.

Skinner, B. F. (1957). Verbal Behavior. New York: Appleton-Century-Crofts. http://www.questia.com/library/book/verb al-behavior-by-b-fskinner.jsp

Witting, A. F. (1981). Psychology of Learning. Schaum's Out-line Series. New York: Mc. Grow Hill. 